\title{
HTLV-1/2 SEROPREVALENCE AND COINFECTION RATE IN BRAZILIAN FIRST-TIME BLOOD DONORS: AN 11-YEAR FOLLOW-UP
}

Mariana Tomazini PINTO*(1,2), Evandra Strazza RODRIGUES*(1,2), Tathiane Maistro MALTA*(1,2), Rochele AZEVEDO(1), Osvaldo Massaiti TAKAYANAGUI(3), Vanderléia Bárbaro VALENTE(1), Eugênia Maria Amorim UBIALI(1), Dimas Tadeu COVAS(1,3) \& Simone KASHIMA(1,2)

\begin{abstract}
SUMMARY
The seroprevalence and geographic distribution of HTLV-1/2 among blood donors are extremely important to transfusion services. We evaluated the seroprevalence of HTLV-1/2 infection among first-time blood donor candidates in Ribeirão Preto city and region. From January 2000 to December 2010, 1,038,489 blood donations were obtained and 301,470 were first-time blood donations. All samples were screened with serological tests for HTLV-1/2 using enzyme immunoassay (EIA). In addition, the frequency of coinfection with hepatitis B virus (HBV), hepatitis C virus (HCV), human immunodeficiency virus (HIV), Chagas disease (CD) and syphilis was also determined. In-house PCR was used as confirmatory test for HTLV-1/2. A total of $296(0.1 \%)$ first-time donors were serologically reactive for HTLV-1/2. Confirmatory PCR of 63 samples showed that 28 were HTLV-1 positive, 13 HTLV-2 positive, 19 negative and three indeterminate. Regarding HTLV coinfection rates, the most prevalent was with HBV (51.3\%) and HCV (35.9\%), but coinfection with HIV, CD and syphilis was also detected. The real number of HTLV-infected individual and coinfection rate in the population is underestimated and epidemiological studies like ours are very informative.
\end{abstract}

KEYWORDS: HTLV-1/2; Blood donors; Seroprevalence; HTLV coinfection.

\section{INTRODUCTION}

Human T cell lymphotropic virus (HTLV) was discovered in 1980, and was the first retrovirus isolated from humans associated with a disease, later denominated HTLV $-1^{35}$. In 1982, a new member of this family was discovered, classified as HTLV-2 ${ }^{21}$ and recently two new types, HTLV-3 and HTLV-4 were identified ${ }^{26,27,42}$. Among these, HTLV-1 is the most widespread and is estimated to infect 15 to 20 million people worldwide ${ }^{13}$.

Currently, HTLV-1 is etiologically associated with adult $\mathrm{T}$ cell leukemia/lymphoma ${ }^{43}$, myelopathy associated with HTLV-1 or tropical spastic paraparesis (HAM/TSP) ${ }^{33}$ and with other inflammatory manifestations including polymyositis, HTLV-1 associated arthropathy, infective dermatitis, uveitis, and Sjögren's syndrome, among others $^{23,28-30,32}$. There are different routes of HTLV transmission, i.e., sexual contact, transfusion of blood components, intravenous injection, and vertical transmission.

The seroprevalence rates differ according to geographic area, socio-demographic composition and individual risk behaviors. HTLV is endemic in Southwest Japan, in the Caribbean basin, in the southeastern United States, Central and South America, and in areas of Central and West Africa ${ }^{34}$.
Several studies have reported that indicators of an individual's low social and economical position, such as few years of education, are associated with HTLV-1/2 infection in endemic and non-endemic $\operatorname{areas}^{11,15,31,39}$. Finally, risk factors such as advanced age, female gender, high proviral load, sexual transmission and low immune response efficiency are also associated with the development of HAM/TSP $2,25,37$.

The serologic test for HTLV-1/2 became mandatory in Brazilian blood banks in 1993 (Brazilian Ministry of Health Law $n^{\circ} 1376$ ), following the guidelines previously established in Japan (1986) and the US $(1988)^{5}$. Since then, several studies have been conducted with data obtained from the screening of HTLV-1/2 in blood banks to estimate the seroprevalence of the virus in various states of Brazil. Due to the large area and population size, it is estimated that Brazil, among all endemic countries, may host the largest absolute number of individuals seropositive for HTLV-1/2, about 2.5 million. This is based on data from blood donations and on only one population-based study in the State of Bahia (Northeast region) ${ }^{9}$.

The prevalence of HTLV-1/2 among blood donors is $0.33 \%$ in Rio de Janeiro, $0.08 \%$ in Manaus (Amazonas State), $0.33 \%$ in Recife (Pernambuco State), $0.08 \%$ in Florianópolis (Santa Catarina State) ${ }^{19}$, and $0.2 \%$ in São Paulo city ${ }^{17}$. The highest prevalence $(1.35 \%)$ is observed among blood donors from Salvador city ${ }^{19}$. Moreover, in the same city the

\footnotetext{
*These authors contributed equally to this manuscript.

This work was developed at Serology and Molecular Biology Laboratory of the Regional Blood Center of Ribeirão Preto, São Paulo, Brazil.

(1)Regional Blood Center of Ribeirão Preto, Ribeirão Preto, SP, Brazil.

(2)Faculty of Pharmaceutical Sciences of Ribeirão Preto, University of São Paulo, Ribeirão Preto, SP, Brazil.

(3)Faculty of Medicine of Ribeirão Preto, University of São Paulo, Ribeirão Preto, SP, Brazil.

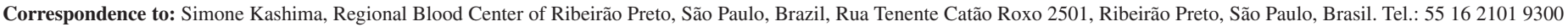
ramal 9311, Fax \# 55162101 9309. E-mail: skashima@hemocentro.fmrp.usp.br
} 


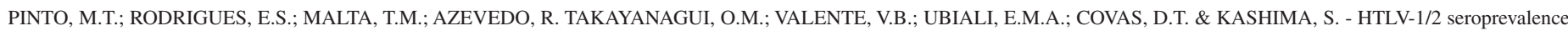
and coinfection rate in Brazilian first-time blood donors: an 11-year follow-up. Rev. Inst. Med. Trop. Sao Paulo, 54(3): 123-9, 2012.

prevalence is estimated $0.8 \%$ among pregnant women ${ }^{4}$ and $25.5 \%$ among intravenous drug users ${ }^{14}$. Although the prevalence of this retrovirus is known in several Brazilian cities, it has not yet been determined among candidates for blood donation in Ribeirão Preto and region, located in the Northwest part of São Paulo State.

Besides HTLV-1/2, other infectious agents are also tested in Brazilian blood banks, including: hepatitis $\mathrm{C}$ virus (HCV), hepatitis B virus (HBV), human immunodeficiency virus type 1/2 (HIV-1/2), syphilis, and Chagas disease $(\mathrm{CD})$. However, there are few reports on the prevalence of coinfection with these agents in HTLV-1/2-seropositive individuals in Brazilian blood banks.

Thus, the objective of the present study was to determine the seroprevalence of HTLV-1/2 among blood donors from the region of Ribeirão Preto over an 11-year period of follow-up, as well as to analyze the rate of coinfection with other infectious diseases (HCV, HBV, HIV$1 / 2$, syphilis and $C D$ ) among donors with reactive serology for the anti-HTLV-1/2 marker.

\section{MATERIALS AND METHODS}

Study Design: The study was conducted between January 2000 and December 2010 at the Regional Blood Center of Ribeirão Preto, São Paulo State, Brazil. The Regional Blood Center of Ribeirão Preto is one of the most important units of the network of Blood Services in São Paulo State and is responsible for the collection, processing and distribution of blood components in 213 municipalities, which correspond to a total of 4.3 million inhabitants.

The procedures for blood donor selection (clinical exam and interview, blood collection, laboratory testing) are relatively uniform throughout the network, following official written guidelines issued by the Brazilian Ministry of Health. Blood donor candidates are submitted to a routine pre-donation questionnaire and clinical examination. Individuals considered eligible for blood donation are 18 to 60 years of age, in good health, and report no risk behavior for retrovirus infection (use of illegal injecting drugs, unsafe sexual practices, etc.) and no history of blood/ blood product transfusion in the previous ten years.

The HTLV-1/2-positive individuals were notified about their positive status and referred for clinical follow up to the Neurology Department of the Clinical Hospital of the Faculty of Medicine in Ribeirão Preto, University of São Paulo.

Laboratory serology tests: HTLV-1/2 diagnosis was established by screening HTLV-1/2 antibodies by enzyme immunoassay (EIA) using serum/plasma samples from all blood donors. During the study period, three different kits were used. The EIA test was selected according to convenience and to the supply available each year: 2000 and 2001 Vironostika ${ }^{\circledR}$ HTLV-I/II (Organon Teknika Corporation, Durham, NC, USA); 2000 to 2009 - Ortho® HTLV-I/HTLV-II Ab-capture ELISA test system (Ortho Clinical Diagnostics Inc, Raritan, New Jersey). In 2006, 2007, 2009 and 2010 Murex HTLV I+II (Murex Biotech Limited, UK) were also used.

Serum samples were also investigated for antibodies against hepatitis B virus (HBV), hepatitis C virus (HCV), human immunodeficiency virus (HIV), Chagas disease, and syphilis. Different commercial kits were used during the study period and samples were considered to be reactive according to the cutoff value of the manufacturer's instructions. All HTLV-1/2 EIA samples that were reactive in the primary test were retested.

Database survey of blood donations: The results of serology screening and personal characteristics of blood donors were included in the database of the Regional Blood Center of Ribeirão Preto. The database information allows us to classify each blood donor as first-time, lapsed or regular and to identify gender and age. We defined regular donors as those who donated blood two or more times a year.

To obtain a genuine result the seroprevalence frequency of HTLV$1 / 2$ infection was determined by dividing the number of HTLV-1/2seropositve first-time donors by the total number of first-time donations tested each year. All HTLV-1/2-positive blood samples are considered to be inappropriate and the blood donor is referred to specialized medical care. The prevalence of coinfection was evaluated in first-time donors which were reagent to anti-HTLV-1/2 EIA.

Coinfection status was considered when the same sample reacted to anti-HTLV-1/2 and to another serological marker in the screening tests for first-time blood donors.

Confirmatory tests: Some HTLV-1/2 EIA reactive samples were confirmed by in-house polymerase chain reaction (PCR) using $5 \mathrm{~mL}$ of the intravenous blood sample collected from each blood donor in tubes containing EDTA as anticoagulant. Blood cells were separated from plasma under aseptic conditions by centrifugation at $900 \times \mathrm{x}$ for 10 minutes at $4{ }^{\circ} \mathrm{C}$. The white cell layer was aspirated together with the red blood cells and placed in sterile $15 \mathrm{~mL}$ polypropylene tubes at $-20^{\circ} \mathrm{C}$. The total DNA of these samples was extracted using the Super Quick Gene DNA Isolation extraction kit (Analytical Genetic Testing Center - AGTC, Denver, Colorado, USA). The DNA obtained was quantified and diluted to a final concentration of $0.1 \mu \mathrm{g} / \mu \mathrm{L}$ DNA.

We then amplified the tax and LTR regions for HTLV-1 and the $p x A, p x B$, and $L T R$ regions for HTLV-2. Reactions were performed in a total volume of $50 \mu \mathrm{L}$ containing 100-200 ng of DNA, $0.25 \mathrm{pmol}$ of each primer, $0.2 \mathrm{mM}$ of $\mathrm{dNTP}, 1 \mathrm{X}$ PCR buffer- $\mathrm{MgCl}_{2}$ and $1.5 \mathrm{U}$ Taq DNA polymerase. Thermocycling was performed in a GeneAmp PCR system 9700 (Applied Biosystems) under the following conditions: an initial cycle at $96^{\circ} \mathrm{C}$ for five minutes, followed by 35 cycles at $95^{\circ} \mathrm{C}$ for one min, $52-61{ }^{\circ} \mathrm{C}$ for one min and $15 \mathrm{sec}$, and $72{ }^{\circ} \mathrm{C}$ for one min and $50 \mathrm{sec}$ with a final extension step of $72{ }^{\circ} \mathrm{C}$ for $10 \mathrm{~min}$. Three $\mu \mathrm{L}$ of the amplified products were used in the nested PCR using a set of internal primers, maintaining the conditions used in the first reaction.

The primer sequences (5'- 3') for HTLV-1 were: Tax region - the external primer sequences were PX01- TCGAAACAGCCCTGCAGATA and PX02- TGAGCTTATGATTTGTCTTCA. The internal primer sequences were PXI1- ATACAAAGTTAACCATGCTT and PXI3AGACGTCAGAGCCTTAGTCT ${ }^{18}$.

$L T R$ region - the external primer sequences were LTR 1CATTTCTACTCTCACACG GCCTCATACAGTACTCTT and LTR2CGCAGTTCAGGAGGCACCAC. The internal primer sequences 


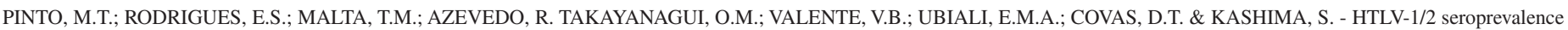
and coinfection rate in Brazilian first-time blood donors: an 11-year follow-up. Rev. Inst. Med. Trop. Sao Paulo, 54(3): 123-9, 2012.

were LTRN1- TTGAAGAATACACCAACATCCC and LTRN2GAACGCGACTCAACCGGCGTGGAT ${ }^{1}$

The primer sequences (5'-3') for HTLV-2 were: LTR region- the external primer sequences were BSQF6-CAGGGCGAGTCATCGACCCAAAAG and BSDR3- GAAGACAATGCTCCTAGGGCGGGC. The internal primer sequences were BSQF2- ACCGTCTCACACAAACAATCCC and BSDR4- GCGGGCCTGCCTATAGCGATG ${ }^{40}$.

pxA region - the external primer sequences were px101GGCAATCTCCTAAAATAGTCT and px102- TGTGTGTAGGA ACATTTTGTA. The internal primer sequences were px103TTACAATCCTGTCTCCTCTCA and px104- AAGTTCTTCTAATCG TTTTAG. pxB region - the external primer sequences were px105GCTTTCCCCACCCATGACATG and px106- GGGCCGTGG TTTCAGTTCCTA. The internal primer sequences were px107-ACCCCA TGTCATATTCTGCCA and px108- AGCCTTTACTTGGGATTGTTT ${ }^{16}$. The amplified products were analyzed by $1 \%$ agarose gel electrophoresis followed by ethidium bromide staining.

Statistical Analysis: Data regarding donor gender, age and different blood donor's types were analyzed by the Chi-square test. The statistical analyses were performed using Prism 5 software (GraphPad Software, Inc., San Diego, CA, USA). Values of $p$ lower than 0.05 were considered to be statistically significant.

\section{RESULTS}

Seroprevalence: Between January 2000 and December 2010, $1,038,489$ voluntary blood donations were obtained from the Regional Blood Center of Ribeirão Preto and 301,470 were first-time blood donations. All samples were screened with serological tests for antiHTLV-1/2 (Table 1). During this period, we identified $387(0.04 \%)$ samples that were reactive for anti-HTLV-1/2, including $296(76.5 \%)$ samples from first-time, $49(12.7 \%)$ from regular and $42(10.8 \%)$ from lapsed blood donors. We observed a high seroprevalence rate in first-time donor group $(p<0.0001)$ when compared with regular and lapsed blood donors (data not shown). In the same period, there were 301,470 first-time blood donations and, as previously mentioned, 296 samples from first-time donors were HTLV-1/2 reactive. Therefore, the rate of HTLV-1/2 seroprevalence of first-time donors was $0.1 \%$ and this rate did not change over the years, with the exception of $2000(0.2 \%)$ (Table 1). All the results shown below are related to the data obtained from first-time donors.

Age and gender distribution: The mean age of subjects with HTVL1/2-reactive samples was 35.2 years throughout the 11 years of the study (Table 1). To investigate the prevalence in different age groups, we divided these subjects into four groups: i) $18-29$, ii) $30-39$, iii) 40-49 and iv) $>50$ years old (Table 1). Of the 296 first-time donors with HTLV-1/2-reactive samples, the majority (37.2\%) were young blood donors (18-29 years old) as supported by statistical analysis ( $p=0.0455$, Chi-square test).

During the analyzed period, the majority of HTLV-1/2-seropositive individuals were females (51\%). Our data demonstrated that from 2000 to 2003 there were a higher frequency of males among HTLV-1/2-reactive blood donors (58\%), and after this period there was a significant increase of HTLV-1/2-reactive females ( $p=0.0410$ ) (data not shown).

PCR confirmatory tests: Some HTLV-1/2-positive samples identified on serologic screening were confirmed by in-house nested PCR. Of the 296 samples reactive to the EIA test, we tested 63 samples by PCR that returned to the institution for a second blood collection. The results showed that 28 samples were HTLV-1 positive, 13 were HTLV-2 positive, three were indeterminate, and 19 were negative (Fig. 1).

Coinfection: A total of 47 donors HTLV-1/2-positive were coinfected with more than one serological marker (Fig. 1). The coinfection rate was $15.9 \%(n=47)$ among HTLV-1/2-reactive samples $(n=296)$ considering a reactive test for another serological marker (Table 2). Of the 47 HTLV1/2 positive samples, 39 were reactive for a second serological marker, among them $51.3 \%, 35.9 \%, 7.7 \%, 2.6 \%$, and $2.6 \%$

Table 1

Distribution of blood donations during 11 years in the Regional Blood Center of Ribeirão Preto: characterization of first-time blood donors, seroprevalence rate of HTLV-1/2 and annual distribution of HTLV-1/2 seroprevalence rate according to the age

\begin{tabular}{|c|c|c|c|c|c|c|c|c|c|}
\hline \multirow[b]{2}{*}{ Year } & \multirow[b]{2}{*}{ Donations (n) } & \multirow{2}{*}{$\begin{array}{l}\text { First-time } \\
\text { donations }\end{array}$} & \multirow{2}{*}{\multicolumn{2}{|c|}{$\begin{array}{cc}\text { First-time do- HTLV-1/2 Se- } & \text { - } \\
\text { nors reactive } & \text { roprevalence } \\
\text { for HTLV-1/2 } & (\%)\end{array}$}} & \multirow{2}{*}{$\begin{array}{l}\text { Mean age of first- } \\
\text { time donors reac- } \\
\text { tive for HTLV-1/2 }\end{array}$} & \multicolumn{4}{|c|}{ Age } \\
\hline & & & & & & $18-29$ & $30-39$ & $40-49$ & $>50$ \\
\hline 2000 & 80,846 & 30,459 & 54 & 0.2 & 34.5 & 21 & 11 & 19 & 3 \\
\hline 2001 & 93,808 & 33,024 & 39 & 0.1 & 35.3 & 14 & 10 & 8 & 7 \\
\hline 2002 & 103,125 & 33,363 & 24 & 0.1 & 38.1 & 6 & 6 & 8 & 4 \\
\hline 2003 & 109,006 & 32,954 & 34 & 0.1 & 33.5 & 11 & 16 & 6 & 1 \\
\hline 2004 & 103,049 & 29,585 & 23 & 0.1 & 34.4 & 10 & 6 & 6 & 1 \\
\hline 2005 & 88,385 & 23,884 & 12 & 0.1 & 34.0 & 5 & 4 & 2 & 1 \\
\hline 2006 & 88,133 & 23,182 & 25 & 0.1 & 36.3 & 10 & 6 & 7 & 2 \\
\hline 2007 & 90,048 & 23,729 & 18 & 0.1 & 30.2 & 11 & 4 & 1 & 2 \\
\hline 2008 & 93,989 & 24,428 & 20 & 0.1 & 34.9 & 8 & 5 & 4 & 3 \\
\hline 2009 & 92,627 & 22,809 & 19 & 0.1 & 38.3 & 6 & 4 & 1 & 8 \\
\hline 2010 & 95,473 & 24,053 & 28 & 0.1 & 37.3 & 8 & 8 & 7 & 5 \\
\hline Total & $1,038,489$ & 301,470 & 296 & - & 35.2 & $110(37.2 \%)$ & $80(27 \%)$ & $69(23.3 \%)$ & $37(12.5 \%)$ \\
\hline
\end{tabular}




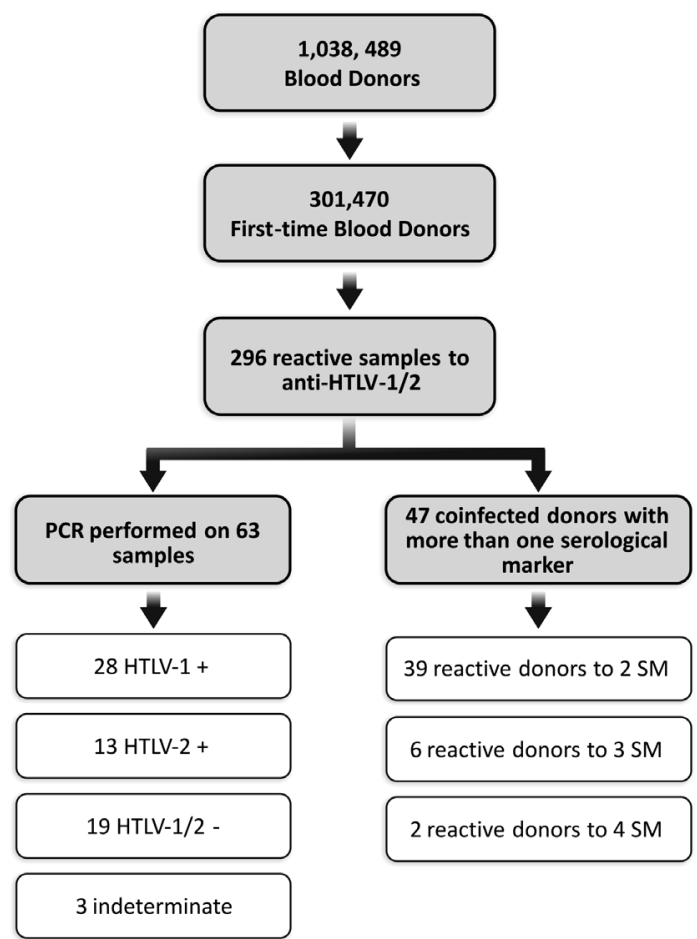

Fig. 1. Flowchart of samples of blood donation which were HTLV-1/2-reactive. SM: serological markers, +: reactive or positive; -: negative; PCR: in-house polymerase chain reaction.

being reactive for anti-HBc, anti-HCV, syphilis, anti-HIV-1/2 and Chagas disease, respectively (Fig. 2).

Besides these cases, we identified six blood donors with triple serological markers: one with anti-HTLV-1/2, anti-HBc and syphilis; one with anti-HTLV-1/2, anti-HBc and HBsAg; one with anti-HTLV-1/2, anti-HCV and anti-HIV-1+2; three with anti-HTLV-1/2, anti-HCV and anti-HBc. We also identified two blood donors with reactivity for four

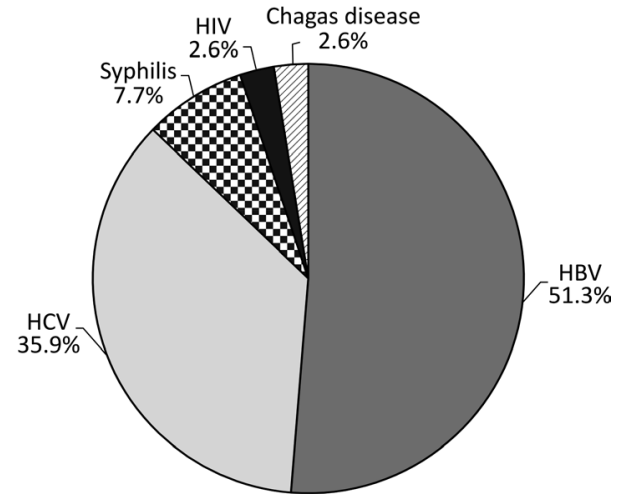

Fig. 2 - Coinfection rate of HTLV-1/2-reactive samples with hepatitis B virus (HBV), hepatitis $\mathrm{C}$ virus (HCV), human immunodeficiency virus (HIV), syphilis and Chagas disease.

serological markers (one donor with anti-HTLV-1/2, anti-HIV-1+2, anti$\mathrm{HBc}$ and anti-HCV; one with anti-HTLV-1/2, anti-HIV-1+2, anti-HBc and syphilis).

The results showed that most coinfections predominated among males $(59.6 \%)$. The two blood donors candidates who presented reactive serology for four markers were males (data not shown).

\section{DISCUSSION}

In this study, during 11 years of follow-up (January, 2000 to December, 2010), we observed a HTLV-1/2 seroprevalence of $0.1 \%$ in the Northwest region of São Paulo State. This seroprevalence rate is higher than cities such as Manaus $(0.08 \%)$, located in Amazonas State, and Florianópolis $(0.08 \%)$, located in Santa Catarina State ${ }^{19}$. In addition, this seroprevalence is lower than São Paulo $(0.2 \%)^{17}$ and Recife city $(0.33 \%)^{19}$ and even lower than Salvador city $(1.35 \%)^{19}$, confirming that this retrovirus has a heterogeneous distribution in Brazil.

Our data demonstrated that most HTLV-infected individuals were

Table 2

Distribution of coinfection markers per year and frequencies rate in relation to gender

\begin{tabular}{|c|c|c|c|c|c|c|c|c|c|c|c|c|c|}
\hline Year & Male & Female & HBV & HCV & HIV & SYP & CD & $\begin{array}{c}\text { anti-HBc/ } \\
\text { HBsAg }\end{array}$ & $\begin{array}{c}\text { anti-HBc/ } \\
\text { HCV }\end{array}$ & $\begin{array}{c}\text { anti-HBc/ } \\
\text { SYP }\end{array}$ & HCV/HIV & $\begin{array}{l}\text { anti-HBc/ } \\
\text { HIV/SYP }\end{array}$ & $\begin{array}{l}\text { anti-HBc/ } \\
\text { HIV/HCV }\end{array}$ \\
\hline 2000 & 8 & 2 & 4 & 3 & - & 1 & - & - & - & - & - & 1 & 1 \\
\hline 2001 & 7 & 2 & 4 & 3 & - & 1 & - & - & - & 1 & - & - & - \\
\hline 2002 & - & 1 & - & 1 & - & - & - & - & - & - & - & - & - \\
\hline 2003 & 5 & 0 & 1 & 2 & - & - & 1 & - & - & - & 1 & - & - \\
\hline 2004 & 2 & 1 & - & - & 1 & - & - & 1 & 1 & - & - & - & - \\
\hline 2005 & 1 & 1 & 2 & - & - & - & - & - & - & - & - & - & - \\
\hline 2006 & 2 & 1 & 2 & - & - & 1 & - & - & - & - & - & - & - \\
\hline 2007 & 1 & 1 & 1 & 1 & - & - & - & - & - & - & - & - & - \\
\hline 2008 & 1 & 1 & - & 2 & - & - & - & - & - & - & - & - & - \\
\hline 2009 & 0 & 4 & 3 & - & - & - & - & - & 1 & - & - & - & - \\
\hline 2010 & 1 & 5 & 3 & 2 & - & - & - & - & 1 & - & - & - & - \\
\hline Total & 28 & 19 & 20 & 14 & 1 & 3 & 1 & 1 & 3 & 1 & 1 & 1 & 1 \\
\hline
\end{tabular}

HBV: hepatitis B virus; HCV: hepatitis C virus; HIV: human immunodeficiency virus; SYP: syphilis; CD: Chagas disease. 


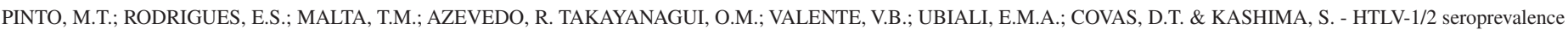
and coinfection rate in Brazilian first-time blood donors: an 11-year follow-up. Rev. Inst. Med. Trop. Sao Paulo, 54(3): 123-9, 2012.

first-time blood donors $(76.5 \%)$. We also observed that HTLV-1/2 seroprevalence increased among females during the last seven years. This fact could be explained by the increase in the number of female blood donors and also by the high efficiency in male to female transmission ${ }^{22}$. Our data showed the higher frequency of seropositivity (37.2\%) among young blood donors (18-29 years old). In fact, the most common blood donors' age in The Regional Blood Center of Ribeirão Preto is 18-29 years old and this could explain our finding.

Our data also revealed that the older the individual ( $>50$ years old), the lower the HTLV prevalence (15.5\%). Our findings disagree with those previously described by CATALAN-SOARES et al. $(2001)^{12}$, who stated that HTLV prevalence increases with age. These findings clearly showed that the profile of HTLV-1-infected individuals is distinct among regions, reinforcing the importance of prevalence studies.

The Health Ministry only recommends EIA for HTLV-1/2 screening of blood donors. Although EIA is highly sensitive, it has a low positive predictive value, especially in low prevalence populations ${ }^{38}$. Because of this, it is necessary to perform confirmatory HTLV tests which, however, are not mandatory by Brazilian law. In this study, we also evaluated the use of a confirmatory test: in-house PCR.

Of the 296 samples that were EIA reactive, 63 were tested by in-house PCR and we were able to determine the result of 60 samples (95\%). Moreover, our in-house PCR was able to discriminate between HTLV-1 and HTLV-2. Only three samples were considered to be indeterminate, demonstrating that the molecular test is a sensitive and accurate test.

In recent years, molecular methods started to be used to confirm HTLV infection status. In parallel, serologic screening tests have undergone a significant evolution, preventing a large number of falsepositive results in EIA tests. These false-positive results are a problem for blood banks because they cause blood components to be discarded and donors to be rejected as unsuitable for future blood donations.

We observed a seroprevalence rate of HTLV-1/2 coinfection higher than $10 \%$ in Ribeirão Preto and region. According to the CASOLI et al. $(2007)^{10}$, HTLV-1/2 coinfection has emerged as a worldwide health problem in the last 20 years, with increasing numbers of HIV/HTLV-1infected individuals in South America and Africa and of HIV/HTLV-2infected individuals in the US and Europe ${ }^{10}$.

The association of HTLV-1/2 with other infectious agents deserves special attention since the interaction between these pathogens may harm patients by stimulating the development of further therapeutic complications, progression of neurologic and immunological disorders and of liver dysfunction.

Our results demonstrated that there are HTLV-positive individuals who had dual serological markers, and most of them $(51.3 \%)$ were coinfected with HBV. These two infections share the same routes of transmission and coinfected cases may be detected in populations that are highly exposed to common risk factors. The diagnosis of HTLV/ HBV in Brazilian blood banks and hospitals is important in view of the risk of blood-borne disease transmission ${ }^{24,36}$.

The second most frequent marker among HTLV-positive individuals was anti-HCV (35.9\%). Some studies have demonstrated that HTLV/ $\mathrm{HCV}$-coinfected individuals diverge in laboratory parameters, involving both liver and immunological patterns. HTLV/HCV coinfection can involve a worse prognosis for HCV infection ${ }^{6,8,41}$.

Another important association is HTLV/HIV coinfection, which induces severe clinical manifestations and opportunistic pathogenic infections ${ }^{20}$. We observed that $2.6 \%$ of HTLV positive subjects are antiHTLV-1/2 and anti-HIV-1/2-reactive. In the state of Bahia, the prevalence of HTLV coinfection reached $20 \%$ among HIV-infected individuals and $4.7 \%$ among women from Feira de Santana city ${ }^{7}$. Some research has shown that HTLV-1 coinfection accelerates the progression of $\operatorname{AIDS}^{7}$, and a recent review reported that overexpression of the HTLV-1/2 Tax proteins seem to play a crucial role in the clinical and immunologic manifestations of HIV/HTLV-1/2 coinfections ${ }^{3}$. However, other authors have suggested that it has no deleterious effects on HIV-1 disease ${ }^{38}$. Due to the impact of HTLV/HIV coinfection in disease progression, it would be important to investigate the coinfection prevalence in different regions and also to adapt public health policies and to provide appropriate programs for the treatment of patients. Interestingly, most cases of coinfection were observed in 2000 and 2001, an occurrence possibly explained by the fact that serological tests have become more efficient over the years.

A shortcoming of this study was that the confirmatory PCR was not performed in all HTLV-1/2 EIA-reactive samples. This is due to the fact that this confirmation is not compulsory for the Brazilian blood bank. Moreover, once the primary test is positive, the majority of the donors did not return (233 HTLV-1/2 EIA positive blood donors) to the institution for a second diagnostic blood collection, although an attempt had been made for them to return. The other infectious diseases (HCV, HBV, HIV-1/2, syphilis and Chagas disease) were tested at our institution only serologically, because their consecutive confirmation is made in the respective reference centers.

Although HTLV infection is an emergent and endemic infectious disease in Brazil, there is no need to notify the National Sanitary Agency. Therefore, the real number of HTLV-infected individuals in the population is underestimated and epidemiological studies like ours are very informative.

\section{RESUMO}

\section{Soroprevalência e taxa de coinfecção do HTLV-1/2 em doadores de sangue de primeira vez brasileiros: 11 anos de estudo}

A soroprevalência e a distribuição geográfica do HTLV-1/2 entre os doadores de sangue são extremamente importantes para os serviços de transfusão. Neste trabalho, foi determinada a soroprevalência da infecção pelo HTLV-1/2 entre os doadores de sangue de primeira vez da cidade de Ribeirão Preto e região. No período de Janeiro de 2000 a Dezembro de 2010, 1.038.489 doações de sangue foram obtidas sendo 301.470 doações de primeira vez. Todas as amostras foram avaliadas com testes sorológicos para HTLV-1/2 usando ensaio imunoenzimático (EIA). Adicionalmente, a frequência de coinfecção com o vírus da hepatite $\mathrm{B}(\mathrm{HBV})$, vírus da hepatite $\mathrm{C}(\mathrm{HCV})$, vírus da imunodeficiência humana (HIV), doença de Chagas (CD) e sífilis também foi determinada. Adicionalmente, foi utilizada uma reação de PCR in-house como teste confirmatório para HTLV-1/2. Um total de $296(0,1 \%)$ doadores de 
PINTO, M.T.; RODRIGUES, E.S.; MALTA, T.M.; AZEVEDO, R. TAKAYANAGUI, O.M.; VALENTE, V.B.; UBIALI, E.M.A.; COVAS, D.T. \& KASHIMA, S. - HTLV-1/2 seroprevalence and coinfection rate in Brazilian first-time blood donors: an 11-year follow-up. Rev. Inst. Med. Trop. Sao Paulo, 54(3): 123-9, 2012.

primeira vez foram sorologicamente reativos para HTLV-1/2. O PCR confirmatório de 63 amostras mostrou que 28 eram HTLV-1 positivas, 13 HTLV-2 positivas, 19 negativas e três indeterminadas. Em relação às taxas de coinfecção com HTLV1/2, a maior prevalência foi com HBV $(51,3 \%)$ e HCV (35,9\%), mas a coinfecção com HIV, CD e sífilis também foram detectadas. O número real de indivíduos infectados pelo HTLV-1 e a taxa de coinfecção na população é subestimado e estudos epidemiológicos como esse são muito informativos.

\section{ACKNOWLEDGMENTS}

This work was supported by Fundação Hemocentro de Ribeirão Preto (FUNDHERP) and Centro Regional de Hemoterapia de Ribeirão Preto $(\mathrm{CRH})$.

\section{DECLARATION OF INTEREST}

All the authors declare they have no conflicting or competing interest. Mariana Tomazini Pinto - analyzed the data and wrote the paper. Evandra Strazza Rodrigues - performed the research study and wrote the paper. Tathiane Maistro Malta - analyzed the data and wrote the paper. Rochele Azevedo - responsible for the HTLV molecular test. Osvaldo Massaiti Takayanagui - clinical support to the HTLV patients. Vanderléia Bárbaro Valente - responsible for the HTLV serological screening. Eugênia Maria Amorim Ubiali - medical clinical coordinator. Dimas Tadeu Covas director president of FUNDHERP, responsible for financial support and comments on the manuscript. Simone Kashima - research coordinator, responsible for critical analysis and comments on the manuscript.

\section{REFERENCES}

1. Alcantara Jr LC, Van Dooren S, Goncalves MS, Kashima S, Costa MC, Santos FL, et al. Globin haplotypes of human T-cell lymphotropic virus type I-infected individuals in Salvador, Bahia, Brazil, suggest a post-Columbian African origin of this virus. J Acquir Immune Defic Syndr. 2003;33:536-42.

2. Bangham CR, Osame M. Cellular immune response to HTLV-1. Oncogene. 2005;24:603546.

3. Beilke MH. Retroviral coinfections: HIV and HTLV. Taking stock of more than a quarter century of research. AIDS Res Hum Retroviruses. 2012;28:139-46.

4. Bittencourt AL, Dourado I, Filho PB, Santos M, Valadao E, Alcantara LC, et al. Human T-cell lymphotropic virus type 1 infection among pregnant women in northeastern Brazil. J Acquir Immune Defic Syndr. 2001;26:490-4.

5. Borducchi DM, Kerbauy J, de Oliveira JS. Linfoma/leucemia de células T do adulto. Rev Assoc Med Bras. 1999;45:63-70.

6. Boschi-Pinto C, Stuver S, Okayama A, Trichopoulos D, Orav EJ, Tsubouchi H, et al. A follow-up study of morbidity and mortality associated with hepatitis $\mathrm{C}$ virus infection and its interaction with human T lymphotropic virus type I in Miyazaki, Japan. J Infect Dis. 2000;181:35-41.

7. Brites C, Sampaio J, Oliveira A. HIV/human T-cell lymphotropic virus coinfection revisited: impact on AIDS progression. AIDS Rev. 2009;11:8-16.

8. Cardoso DF, Souza FV, Fonseca LA, Duarte AJ, Casseb J. Influence of human T-cell lymphotropic virus type 1 (HTLV-1) infection on laboratory parameters of patients with chronic hepatitis C virus. Rev Inst Med Trop Sao Paulo. 2009;51:325-9.

9. Carneiro-Proietti AB, Ribas JG, Catalan-Soares BC, Martins ML, Brito-Melo GE, Martins-Filho OA, et al. Infecção e doença pelos virus linfotrópicos humanos de celulas T (HTLV-I/II) no Brasil. Rev Soc Bras Med Trop. 2002;35:499-508.
10. Casoli C, Pilotti E, Bertazzoni U. Molecular and cellular interactions of HIV-1/HTLV coinfection and impact on AIDS progression. AIDS Rev. 2007;9:140-9.

11. Catalan-Soares B, Carneiro-Proietti AB, Proietti FA, Interdisciplinary HTLV Research Group. Heterogeneous geographic distribution of human T-cell lymphotropic viruses I and II (HTLV-I/II): serological screening prevalence rates in blood donors from large urban areas in Brazil. Cad Saude Publica. 2005;21:926-31.

12. Catalan-Soares BC, Proietti FA, Carneiro-Proietti ABF. Human T-cell lymphotropic viruses (HTLV) in the last decade (1990-2000): epidemiological aspects. Rev Bras Epidemiol. 2001;4:81-95.

13. de Thé G, Bomford R. An HTLV-I vaccine: why, how, for whom? AIDS Res Hum Retroviruses. 1993;9:381-6.

14. Dourado I, Andrade T, Carpenter CL, Galvao-Castro B. Risk factors for human T cell lymphotropic virus type I among injecting drug users in northeast Brazil: possibly greater efficiency of male to female transmission. Mem Inst Oswaldo Cruz. 1999;94:13-8.

15. Dourado I, Alcantara LC, Barreto ML, da Gloria Teixeira M, Galvao-Castro B. HTLV-I in the general population of Salvador, Brazil: a city with African ethnic and sociodemographic characteristics. J Acquir Immune Defic Syndr. 2003;34:527-31.

16. Eiraku N, Novoa P, da Costa Ferreira M, Monken C, Ishak R, da Costa Ferreira O, et al Identification and characterization of a new and distinct molecular subtype of human T-cell lymphotropic virus type 2. J Virol. 1996;70:1481-92.

17. Ferreira Junior OC, Vaz RS, Carvalho MB, Guerra C, Fabron AL, Rosemblit J, et al. Human T-lymphotropic virus type I and type II infections and correlation with risk factors in blood donors from Sao Paulo, Brazil. Transfusion. 1995;35:258-63.

18. Furukawa Y, Yamashita M, Usuku K, Izumo S, Nakagawa M, Osame M. Phylogenetic subgroups of human T cell lymphotropic virus (HTLV) type I in the tax gene and their association with different risks for HTLV-I-associated myelopathy/tropical spastic paraparesis. J Infect Dis. 2000;182:1343-9.

19. Galvao-Castro B, Loures L, Rodrigues LG, Sereno A, Ferreira Junior OC, Franco LG, et al. Distribution of human T-lymphotropic virus type I among blood donors: a nationwide Brazilian study. Transfusion. 1997;37:242-3.

20. Gudo ES, Bhatt NB, Bila DR, Abreu CM, Tanuri A, Savino W, et al. Co-infection by human immunodeficiency virus type 1 (HIV-1) and human T cell leukemia virus type 1 (HTLV-1): does immune activation lead to a faster progression to AIDS? BMC Infect Dis. 2009;9:211.

21. Kalyanaraman VS, Sarngadharan MG, Robert-Guroff M, Miyoshi I, Golde D, Gallo RC A new subtype of human T-cell leukemia virus (HTLV-II) associated with a T-cell variant of hairy cell leukemia. Science. 1982;218(4572):571-3.

22. Kaplan JE, Khabbaz RF, Murphy EL, Hermansen S, Roberts C, Lal R, et al. Male-tofemale transmission of human T-cell lymphotropic virus types I and II: association with viral load. The Retrovirus Epidemiology Donor Study Group. J Acquir Immune Defic Syndr Hum Retrovirol. 1996;12:193-201.

23. LaGrenade L, Hanchard B, Fletcher V, Cranston B, Blattner W. Infective dermatitis of Jamaican children: a marker for HTLV-I infection. Lancet. 1990;336(8727):1345-7.

24. Lima LH, Viana MC. Prevalence and risk factors for HIV, syphilis, hepatitis B, hepatitis $\mathrm{C}$, and HTLV-I/II infection in low-income postpartum and pregnant women in Greater Metropolitan Vitoria, Espirito Santo State, Brazil. Cad Saude Publica. 2009;25:66876.

25. Lima MA, Bica RB, Araujo AQ. Gender influence on the progression of HTLV-I associated myelopathy/tropical spastic paraparesis. J Neurol Neurosurg Psychiatry. 2005;76:2946.

26. Mahieux R, Gessain A. Les nouveaux retrovirus humains HTLV-3 et HTLV-4. Med Trop (Mars). 2005;65:525-8 
PINTO, M.T.; RODRIGUES, E.S.; MALTA, T.M.; AZEVEDO, R. TAKAYANAGUI, O.M.; VALENTE, V.B.; UBIALI, E.M.A.; COVAS, D.T. \& KASHIMA, S. - HTLV-1/2 seroprevalence and coinfection rate in Brazilian first-time blood donors: an 11-year follow-up. Rev. Inst. Med. Trop. Sao Paulo, 54(3): 123-9, 2012.

27. Mahieux R, Gessain A. The human HTLV-3 and HTLV-4 retroviruses: new members of the HTLV family. Pathol Biol (Paris). 2009;57:161-6.

28. Mariette X, Agbalika F, Zucker-Franklin D, Clerc D, Janin A, Cherot P, et al. Detection of the tax gene of HTLV-I in labial salivary glands from patients with Sjogren's syndrome and other diseases of the oral cavity. Clin Exp Rheumatol. 2000;18:341-7.

29. Mochizuki M, Ono A, Ikeda E, Hikita N, Watanabe T, Yamaguchi K, et al. HTLV-I uveitis. J Acquir Immune Defic Syndr Hum Retrovirol. 1996;13(Suppl 1):S50-6.

30. Morgan OS, Rodgers-Johnson P, Mora C, Char G. HTLV-1 and polymyositis in Jamaica. Lancet. 1989;2(8673):1184-7.

31. Moxoto I, Boa-Sorte N, Nunes C, Mota A, Dumas A, Dourado I, et al. Perfil sociodemográfico e comportamental de mulheres infectadas pelo HTLV-1 em Salvador, Bahia, uma área endêmica para HTLV. Rev Soc Bras Med Trop. 2007;40:3741.

32. Nishioka K, Maruyama I, Sato K, Kitajima I, Nakajima Y, Osame M. Chronic inflammatory arthropathy associated with HTLV-I. Lancet. 1989;1(8635):441.

33. Osame M, Usuku K, Izumo S, Ijichi N, Amitani H, Igata A, et al. HTLV-I associated myelopathy, a new clinical entity. Lancet. 1986;1(8488):1031-2.

34. Pawson R, Mufti GJ, Pagliuca A. Management of adult T-cell leukaemia/lymphoma. Br J Haematol. 1998;100:453-8.

35. Poiesz BJ, Ruscetti FW, Gazdar AF, Bunn PA, Minna JD, Gallo RC. Detection and isolation of type $C$ retrovirus particles from fresh and cultured lymphocytes of a patient with cutaneous T-cell lymphoma. Proc Natl Acad Sci USA. 1980;77:7415-9.

36. Portelinha Filho AM, Nascimento CU, Tannouri TN, Troiani C, Ascencio EL, Bonfim $\mathrm{R}$, et al. Seroprevalence of HBV, HCV and HIV co-infection in selected individuals from state of Sao Paulo, Brazil. Mem Inst Oswaldo Cruz. 2009;104:960-3.
37. Saito M, Nakagawa M, Kaseda S, Matsuzaki T, Jonosono M, Eiraku N, et al. Decreased human T lymphotropic virus type I (HTLV-I) provirus load and alteration in T cell phenotype after interferon-alpha therapy for HTLV-I-associated myelopathy/tropical spastic paraparesis. J Infect Dis. 2004;189:29-40.

38. Salles NA, Sabino EC, Barreto CC, Barreto AM, Otani MM, Chamone DF. Descarte de bolsas de sangue e prevalência de doenças infecciosas em doadores de sangue da Fundação Pró-Sangue /Hemocentro de São Paulo. Rev Panam Salud Publica. 2003; 13:111-6

39. Soares BC, Proietti AB, Proietti FA, Interdisciplinary HTLV-I/II Research Group HTLV-I/II and blood donors: determinants associated with seropositivity in a low risk population. Rev Saude Publica. 2003;37:470-6.

40. Switzer WM, Pieniazek D, Swanson P, Samdal HH, Soriano V, Khabbaz RF, et al Phylogenetic relationship and geographic distribution of multiple human T-cell lymphotropic virus type II subtypes. J Virol. 1995;69:621-32.

41. Victoria MB, Victoria F da S, Torres KL, Kashima S, Covas DT, Malheiro A. Epidemiology of HIV/HCV coinfection in patients cared for at the Tropical Medicine Foundation of Amazonas. Braz J Infect Dis. 2010;14:135-40.

42. Wolfe ND, Heneine W, Carr JK, Garcia AD, Shanmugam V, Tamoufe U, et al. Emergence of unique primate T-lymphotropic viruses among central African bushmeat hunters. Proc Natl Acad Sci USA. 2005;102:7994-9.

43. Yoshida M, Seiki M, Yamaguchi K, Takatsuki K. Monoclonal integration of human T-cell leukemia provirus in all primary tumors of adult T-cell leukemia suggest causative role of human T-cell leukemia virus in the disease. Proc Natl Acad Sci USA. 1984;81:2534-7.

Received: 14 December 2011 Accepted: 24 February 2012 


\section{Revista do Instituto de Medicina Tropical de São Paulo on line.}

Publications from 1987 to the present data are now available on:

http://www.scielo.br/rimtsp

PAST ISSUES 1959-1989 (PDF)

www.imt.usp.br/portal/

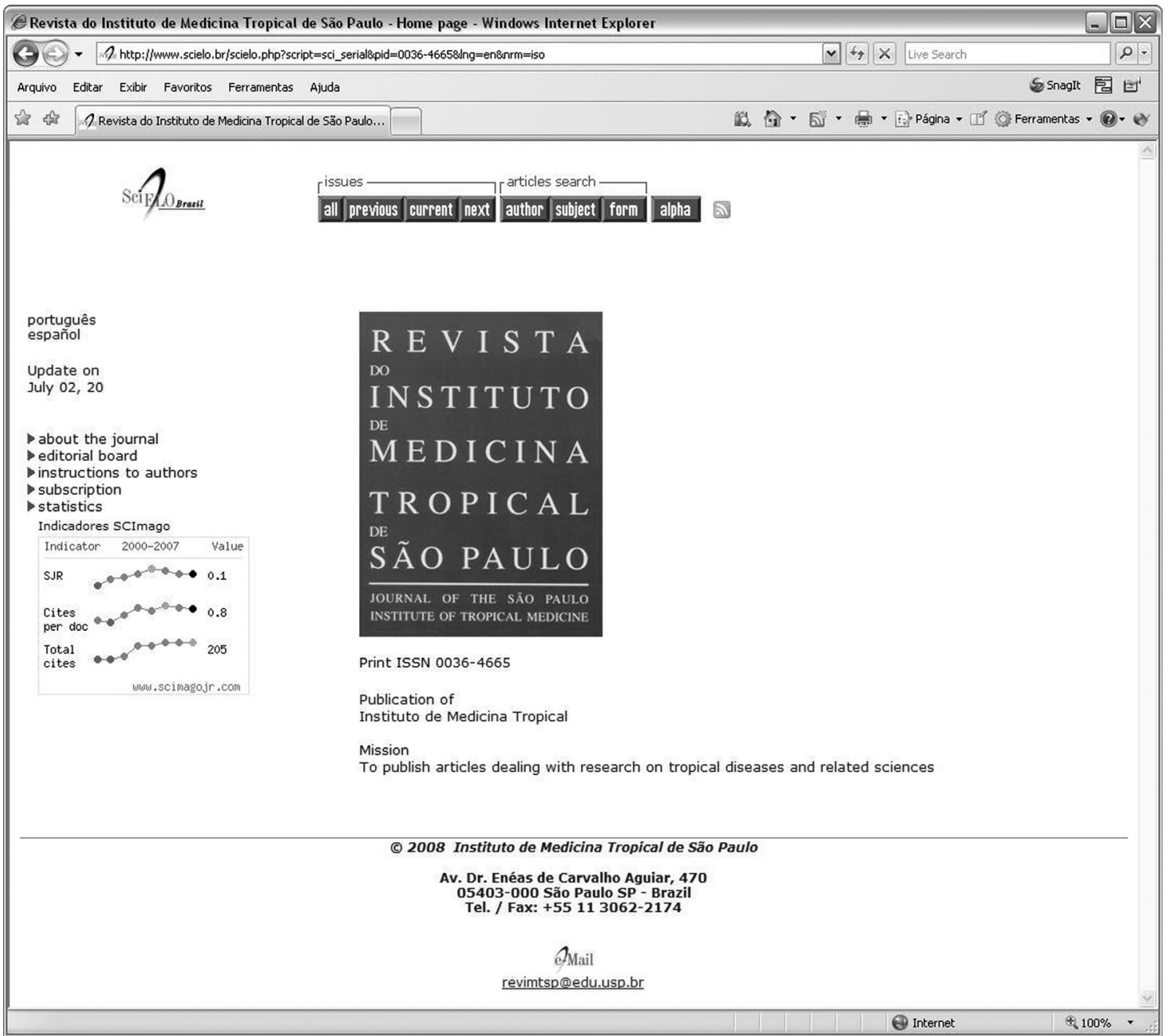

SciELO - The Scientific Electronic Library OnLine - SciELO is an electronic virtual covering a selected collection of Brazilian scientific journals.

The library is an integral part of a project being developed by FAPESP - Fundação de Amparo à Pesquisa do Estado de São Paulo, in partnership with BIREME - the Latin American and Caribbean Center on Health Sciences Information.

SciELO interface provides access to its serials collection via an alphabetic list of titles or a subject index or a search by word of serial titles, publisher names, city of publication and subject.

The interface also provides access to the full text of articles via author index or subject index or a search form on article elements such as author names, words from title, subject and words from full text.

FAPESP/BIREME Project on Scientific Electronic Publications Latin American and Caribbean Center on Health Sciences Information

Rua Botucatu 862 - 04023-901 São Paulo, SP - Brazil

Tel. (011) 5576-9863

scielo@bireme.br 